\title{
Temperature Impacts on the Cardiac Activity of the Snail Pomacea canaliculata from Shatt Al-Arab Region, Basrah, Iraq
}

Malik H. Ali
Hanaa H. Mohammed

Huda K. Ahmed

\author{
Received 12/2/2019, Accepted 12/11/2019, Published 1/6/2020
}

This work is licensed under a Creative Commons Attribution 4.0 International License.

\begin{abstract}
:
The effects of temperature on an exotic aquatic snail Pomacea canaliculata (Lamarck, 1819) collected from the Shatt Al-Arab intertidal zone were investigated. A series of laboratory experiments were conducted during the summer period of 2017. Individuals of new born snails hatched in the laboratory from adult snails were collected from Shatt Al-Arab intertidal zone, and subjected to five fixed temperatures: 15 , 25, 35, 40 and $45 \mathrm{C}^{\circ}$, after short term thermal acclimation. The heartbeats (HB) were counted at each temperature level. The results showed significant direct increase of $\mathrm{HB}$ from $15 \mathrm{C}^{\circ}(19.8 \mathrm{HB} / \mathrm{min})$ up to 25 $\mathrm{C}^{\circ}(76 \mathrm{HB} / \mathrm{min})(\mathrm{P}<0.05)$ as well as from $25 \mathrm{C}^{\circ}$ to $35 \mathrm{C}^{\circ}(93 \mathrm{HB} / \mathrm{min})$. At $40 \mathrm{C}^{\circ}$ the snail $\mathrm{HB}$ shows only slight insignificant increase $(79 \mathrm{HB} / \mathrm{min})$. At $45^{\circ} \mathrm{C}$ the $\mathrm{HB}$ became irregular and showed negative thermo cardiac activity (HB dropped to 50.4/min). The minimum HB rate of $11 / \mathrm{min}$ was recorded at $15 \mathrm{C}^{\circ}$ and the maximum value of $119 \mathrm{HB} / \mathrm{min}$ was recorded at $40 \mathrm{C}^{\mathrm{o}}$. The study concluded that $P$. canaliculata can be highly stressed when exposed to extreme temperature experienced during the prolonged summer months and will no longer tolerate living in the intertidal zone of Shatt Al-Arab.
\end{abstract}

Key words: Heartbeats, Intertidal zone, Pomacea canaliculata, Shatt Al-Arab.

\section{Introduction:}

The snail P. canaliculata (Lamarck, 1819) is a freshwater species, originally native to South America tropical and subtropical regions. Reports mentioned the wide dispersal of this species into other geographical regions mainly in North America and Asia for agricultural and aquarium purposes (1, 2,3 ), and due to its capability to tolerate wide range of environmental conditions as well as consuming wide variety of food, the species was able to expand its distribution and became one of the effective invasive animal in the world, and a harmful pest of wetland crops such as rice (4). In Iraq although the species has been reported in the recent ten years (2007-2017) in Baghdad and Shatt Al-Arab $(5,6)$, to the best of our knowledge its existence in small rivers and canals of agricultural farms is indicated in Babylon during 1990-1991. At that time, it was used in fish aquariums and therefore large numbers of the snail were transferrted to Basrah city and subsequently the species invaded Shatt Al-Arab habitat. Also the species is known as an important intermediate host of dangerous nematode

Marine Science Center, University of Basrah, Basrah, Iraq.

*Corresponding author: malikh.ali1954@ gmail.com

*ORCID ID: https://orcid.org/0000-0001-5139-6795
Angiostrongylus cantonensis parasites (7) which is adding a further health factor effect to the other ecoagricultural factors.

Ecologically, as an exotic species to the intertidal zone of Shatt Al-Arab river system, the snail may be causing great impacts on the other native gastropods living in the habitat (8) due to the fact that the Mollusca's community of Shatt AlArab is comprised of several gastropod's species namely; Neritina schlaeflii, Theodoxus jordani, Melanoides tuberculata, Melanopsis praemorsum and Radix auricularia (9), all of them are much smaller in size and have less active mobility than $P$. canaliculata.

Climate change studies indicated that thermal factors play a major role in the success of the invader species into their spreading in an area $(10,11,12,13)$. In the few previous decades the natural ecosystems of Shatt Al-Arab estuary and the Mesopotamean marshes have been subjected to apparent environmental changes such as rising of temperature, rising of water salinity, reducing the freshwater discharge and experienced longer period of drought seasons (14). These changes have various direct and indirect impacts on the biophysiology of the indigenous species; mainly the macrobenthos which generally show pronounce 
decline in their population densities and clear shifting in their distribution.

Fortunately, the energy costs of biophysiological processes were assessed for many macrobenthic invertebrates living in Shatt Al-Arab River system during the last three decades (1980, 1990 and 2000s) of the previous century $(15,16$, 17). In these studies, the oxygen consumption rates were used as indirect measure of the metabolic rates which is an essential part of the energy budget of the species population.

Recently many researchers have used heartbeat activity as a function of the thermal and salinity stressors in addition to the oxygen consumption methods; these are $(18,19,20,21,22$, and 23). In the present work we used the heartbeat method as a measure of the thermal responses of an invader gastropod species from Shatt Al-Arab intertidal zone, which is part of a wider program aiming at initiating heartbeats activity measurements methods for studying the biophysiological responses of macroinvertebrates related to the changes in environmental temperature. According to Iraq's state-run Metrological Department 2017 Iraq is enduring the year's hottest day to date, with temperatures soaring to as much as $53.9^{\circ}$ Celsius in the City of Basrah.

\section{Materials and Methods:}

\section{Collection of adult snails:}

Adult snails of P. canaliculata were collected by hand from the intertidal area of Shatt Al-Arab estuary, at Tannooma site ( $30^{\circ} 31^{\prime} 26-42^{\prime \prime}$ $\mathrm{N}, 47^{\circ} 50^{\prime} 42-75^{\prime \prime} \mathrm{E}$ ), in June 2017. During low tide period, large number of adult snail Pomacea canaliculata were found within the submerged plants, typha and reeds, many of them putting their pink color egg sacs on the typha plants above the high tide water level (Fig.1).

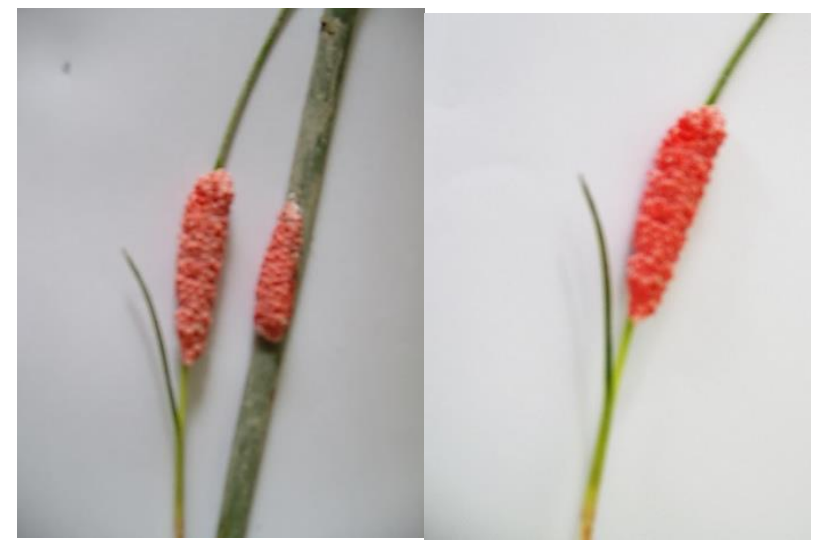

Figure1. Colored egg sacs of Pomacea canaliculata on the Typha plant

\section{Hatching of young snails:}

Several adult snails were taken from the field and reared at laboratory condition, in a glass tank $(60 \times 12 \times 12 \mathrm{~mm})$. Little amount of filtered river water (1.5 ppt. salinity) was maintained in the tank. Few days later some snails laid their egg sacs were put on the walls of the tank above the water level. After an average of two weeks, the eggs hatched to new born snails which have fine transparency shells (Fig. 2).

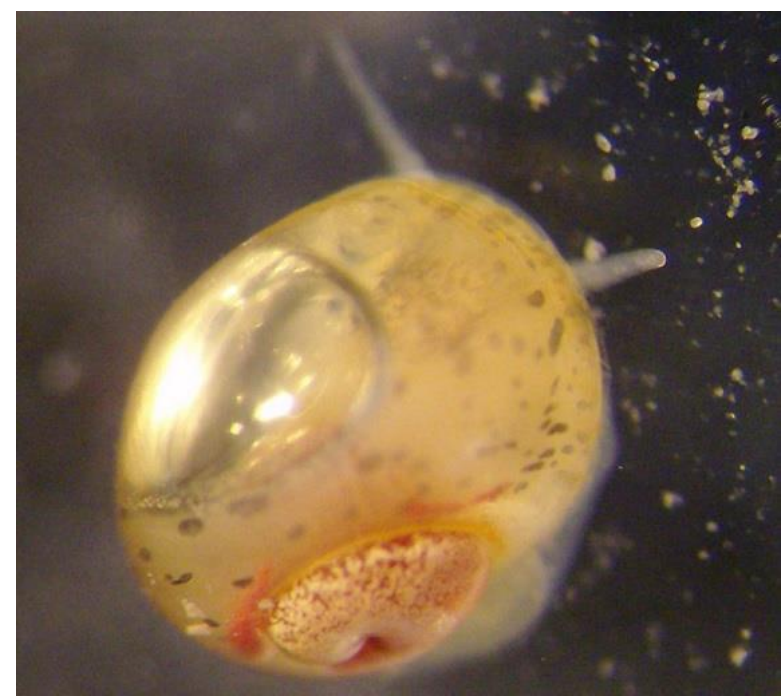

Figure 2. Newly hatching Pomacea canaliculata

\section{Heartbeat measurements}

The cardiac activity of the new born snails was measured by counting the heartbeat directly under the dissecting microscope, where the internal organs of the snail can be easily seen through the shell (Fig. 2).

The snails during the incubation period experienced a hot summer condition, where the laboratory temperature ranged between 30 and $35{ }^{\circ} \mathrm{C}$. Thirty individuals of the snail $(0.062 \mathrm{~g}$ mean individual fresh weight $\mathrm{N}=25$ ) were isolated in a well oxygenated jar of water at $30{ }^{\circ} \mathrm{C}$ water temperature. The thermal impacts on the heartbeat rate were measured at 5 temperature levels, 15, 25, 35, 40 and $45{ }^{\circ} \mathrm{C}$. In each experiment, 10 snails were acclimated to the exposed temperatures for a period of 30 minutes by using a technique of gradual rising or reducing of temperature by a rate of $0.2{ }^{\circ} \mathrm{C} / \mathrm{min}$ $(24,25)$. Each individual snail was placed in a small plastic petri dish with some water taken from the acclimation jar and examined under the dissecting microscope for the heartbeat rate, after measurement the snail was returned back to the acclimation jar. A total of 30 reading for 30 individuals were taken at each test temperature. Data analysis means, variance and statistical comparison (ANOVA), were done by SPSS program. 


\section{Results}

The values of the mean heartbeats rates and the standard errors (SE) at the five test temperatures $\left(15,25,35,40\right.$ and $\left.45^{\circ} \mathrm{C}\right)$ are given in Table 1 , and shown in Fig. 3.

Table 1. The values of the mean heartbeat rates and the S.E. of $P$. canaliculata at the 5 experimental temperatures.

\begin{tabular}{cccccc}
\hline Temperatures $\left(\mathbf{C}^{\mathbf{0}}\right)$ & Mean Heartbeats No./min & $\mathbf{S . E} \pm$ & $\mathbf{N}$ & Min. & Max \\
\hline 15 & 19.8 & 1.35 & 30 & 11 & 39 \\
25 & 76.0 & 0.96 & 30 & 60 & 86 \\
35 & 93.1 & 1.12 & 30 & 78 & 100 \\
40 & 97.0 & 6.50 & 25 & 47 & 119 \\
45 & 50.4 & 4.58 & 25 & 22 & 84 \\
\hline
\end{tabular}

The results showed that cardiac activity of the snail is a direct positive function of temperature at the thermal limits between $15-40{ }^{\circ} \mathrm{C}$, in general. The curve of the mean values plots (Fig. 3) shows high increasing of heartbeats activity (HB:No./min) by rising the temperature from $15^{\circ} \mathrm{C}$ to $25 \mathrm{C}^{\circ}$ ( $\mathrm{HB}$ 19.8 up to 76 ), and from $25^{\circ} \mathrm{C}$ to $35^{\circ} \mathrm{C}$ (HB 76 up to 93 ), but by rising the temperature $5^{\circ} \mathrm{C}$ i. e.: from $35^{\circ} \mathrm{C}$ to $40{ }^{\circ} \mathrm{C}$, the snails show only slight increase in the mean $\mathrm{HB}$ (93.1 up to $97.0 \mathrm{HB}$ ), which is statistically insignificant (Table 2). At $45{ }^{\circ} \mathrm{C}$, the snail's HB become irregular and they were thermo negative, their cardiac activity dropped from 97.0 $\mathrm{HB} / \mathrm{min}$ at $40{ }^{\circ} \mathrm{C}$ down to $50.4 \mathrm{HB} / \mathrm{min}$ at $45^{\circ} \mathrm{C}$.

The results also indicated that at a temperature ranged between $15-35{ }^{\circ} \mathrm{C}$, the snails means $\mathrm{HB}$ values were relatively more stable as their S.E.'s values ranged between 0.96-1.35, whereas the variability of rates about the mean was very high at the temperatures $40^{\circ} \mathrm{C}$ and $45^{\circ} \mathrm{C}$ (SE: 6.50 and 4.58 respectively). The minimum $\mathrm{HB}$ value (11) was recorded at $15^{\circ} \mathrm{C}$ and the highest HB value (119) was recorded at $40^{\circ} \mathrm{C}$.

Data of the heartbeat rates counted at different test temperatures were statistically analyzed for multiple comparisons of means (SPSS program). The cumulative relative frequency distribution of the data as plotted with normal probability scale reveals a reverse S-shape curve (Fig.4) which indicated a platykurtic distribution, i.e. showed a slight departure from normality. Therefore, all pairs of means were compared using Tukey test with Unequal sample sizes, as given in Table 2.

The results showed that the mean values of the heartbeats were significantly different $(\mathrm{P}<0.05)$, at the following comparison:

$15^{\circ} \mathrm{C}$ and $\left(25,35,40,45^{\circ} \mathrm{C}\right) ; 25^{\circ} \mathrm{C}$ and $\left(35,40,45^{\circ} \mathrm{C}\right) ; 35^{\circ} \mathrm{C}\left(15,25,45^{\circ} \mathrm{C}\right) ; 40^{\circ} \mathrm{C}(15,25$, $\left.45{ }^{\circ} \mathrm{C}\right) ; 45^{\circ} \mathrm{C}$ and all other temperatures. One exception was between $35^{\circ} \mathrm{C}$ and $40^{\circ} \mathrm{C}$ which was insignificantly different $(\mathrm{P}>0.05)$ (Table 2).

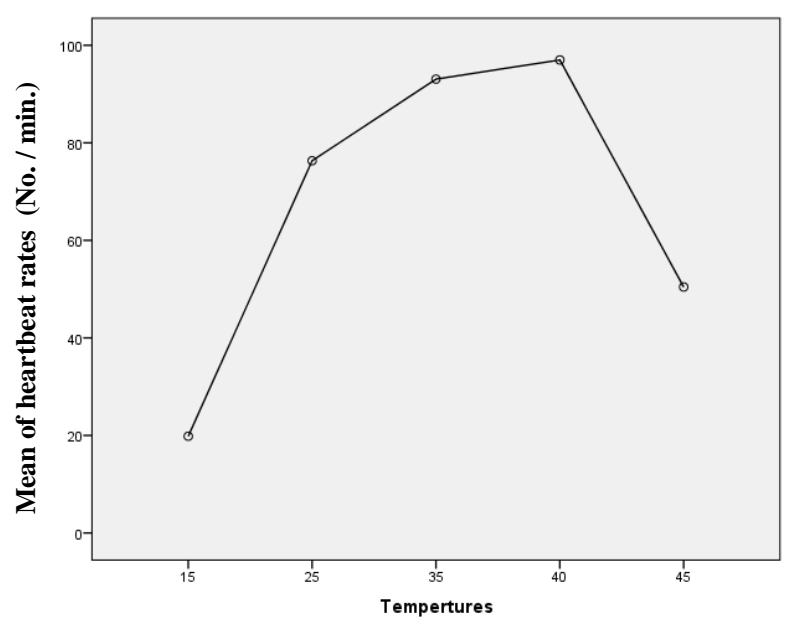

Figure3. The mean heartbeat rates (No./ min.) of $P$. canaliculata from Basrah at the 5 experimental temperatures.

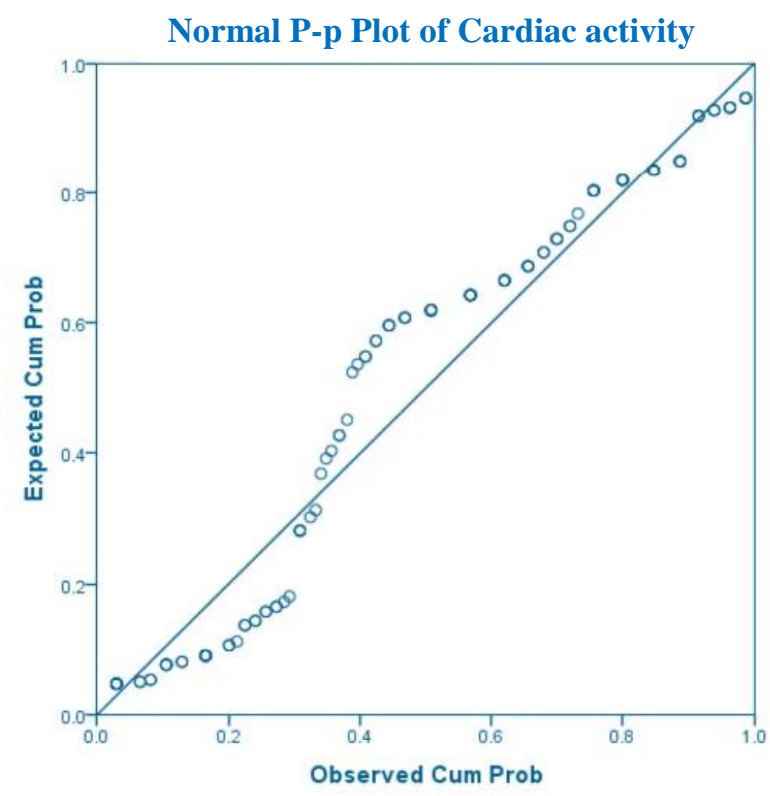

Figure4. Cumulative and observed relative frequency distribution of heartbeat rates of $P$. canaliculata from Basrah. 
Table2. Multiple comparisons, Tukey test of the means of heartbeat rates (no./min.) at the 5 experimental temperatures of $P$. canaliculata from Basrah.

\begin{tabular}{cccc}
\hline \multicolumn{2}{c}{ Temperature } & Mean Difference & Std. Error \\
\hline \multirow{6}{*}{15} & 25 & $-56.495^{*}$ & 3.443 \\
& 35 & $-73.228^{*}$ & 3.443 \\
& 40 & $-77.161^{*}$ & 3.984 \\
25 & 45 & $-30.599^{*}$ & 4.138 \\
& 15 & $56.495^{*}$ & 3.443 \\
& 35 & $-16.733^{*}$ & 3.471 \\
35 & 40 & $-20.667^{*}$ & 4.008 \\
& 45 & $25.896^{*}$ & 4.161 \\
& 15 & $73.228^{*}$ & 3.443 \\
40 & 25 & $16.733^{*}$ & 3.471 \\
& 40 & -3.933 & 4.008 \\
& 45 & $42.629^{*}$ & 4.161 \\
& 15 & $77.161^{*}$ & 3.984 \\
45 & 25 & $20.667^{*}$ & 4.008 \\
& 35 & 3.933 & 4.008 \\
& 45 & $46.563^{*}$ & 4.619 \\
& 15 & $30.599^{*}$ & 4.138 \\
& 25 & $-25.896^{*}$ & 4.161 \\
& 35 & $-42.629^{*}$ & 4.161 \\
& 40 & $-46.563^{*}$ & 4.619 \\
\hline
\end{tabular}

*the mean difference is significant at the 0.05 level.

\section{Discussion:}

The results of the present investigation revealed differences in the heartbeat rates (or cardiac activity) of the exotic snail Pomacea canaliculata, tested under five fixed temperatures, ranged from $15{ }^{\circ} \mathrm{C}$ to $45^{\circ} \mathrm{C}$. The heartbeat rate like some other techniques (for example respirometry) is a simplified measure of the metabolic rate of the invertebrate animals $(20,21,23,26)$.The majority of the studies use these experimental techniques under laboratory conditions due to difficulties and complexity of the field measurements. But, in fact, laboratory data usually doesn't reflect the field data $(18,20,27)$. Therefore, researchers followed many processing to keep their experimental animals under conditions nearly approaching that of the field. One of these techniques is the thermal acclimation in which the animals are subjected to various kinds of long and short terms thermal acclimation periods according to the target of the study.

It is well known that temperature is a key factor controlling the physiological processes of organisms especially the poikelotherm animals such as invertebrates. In these animals any changes in temperature can directly affect the measured biophysiologicl parameter. Furthermore, because the temperature change responses are a function of size, the small sized animals are more sensitive to such thermal changes $(28,29)$. Therefore, in the methodology $(26,30)$ as well as in the present study, in order to avoidany thermal shock we have used the gradual rising or reducing of temperature $\left(0.2{ }^{\circ} \mathrm{C} / \mathrm{min}\right)$ when ramped from one temperature to another (e.g. $15{ }^{\circ} \mathrm{C}$ to $20{ }^{\circ} \mathrm{C}$ ) in the course of the acclimation of the snails to the exposure temperature.

Although the experimental work had done on new born snails (six days olds, $4.0 \mathrm{~mm}$. width) hatched in the laboratory, yet the parents of these snails were collected from the intertidal zone of Shatt Al-Arab estuary in Basrah City. In this habitat, various individuals of the snails population (adults and juveniles) could be exposed to a wide range of temperature variation seasonally at their habitat, and in fact the thermal limits are shifted towards the warm ranges, due to the geographical location. In addition to that, Basrah region experienced apparent rising of temperature during the past two decades, particularly during the hot summer months, where longer periods of extreme temperature (above $50^{\circ} \mathrm{C}$ ) were increasingly recorded (local metrological records).

Under these extreme thermal conditions, the snails as well as other benthic invertebrates living in the intertidal zone (especially during low tide period) are subjected to a significant thermal stress. Recent researches concerning climate change (especially temperature) have given considerable attention to the intertidal habitats, expecting significant further effects on the existence and distribution of intertidal species $(10,31)$. To have more understanding and to predict to what extent can be an exotic species successfully distributed in such habitat, more detailed data of the diurnal and the annual thermal history of the habitat and that of the region are needed to recorded and analyzed (32). As this dataset is not available, especially to the Shatt Al-Arab intertidal habitats, a full understanding of the future status of $P$. canaliculata cannot be concluded at this stage. However, according to the latest recording of the Iraqi staterun Metrological Department as well as our field recording, Basrah City has experienced the year's hottest day to date, during July 2017, with temperatures rising as much as 53.9 Celsius. Therefore, and based on our results of the thermalheartbeat rate experiments, $P$. canaliculata can be highly thermally stressed during the Summer season, particularly during July and August in which the animal could be subjected to sub-lethal or lethal conditions of worming stress. For this reason we tested the response of the present species to high temperature levels, i.e $35-45{ }^{\circ} \mathrm{C}$. However, the results addressed a significant direct effect of thermal change on the cardiac activity of the snail. For example if we consider the $25^{\circ} \mathrm{C}$ as a normal field water temperature, a depletion of water 
temperature by $10{ }^{\circ} \mathrm{C}$ resulted in reducing the heartbeat rate of the snails by $74 \%$. On the other hand, an increase of temperature from $25^{\circ} \mathrm{C}$ to 35 ${ }^{\circ} \mathrm{C}$ resulted in $12.3 \%$ increment of heartbeat rate, beyond the $35{ }^{\circ} \mathrm{C}$ level, the snails cardiac activity showed either insignificant increase when exposed to $40{ }^{\circ} \mathrm{C}$, or they were expressed a reversed response when exposed to $45^{\circ} \mathrm{C}$ as the heartbeat rate reduced significantly down to $46 \%$, compared with the rate at $35 \mathrm{C}^{\circ}$. These results raise a question: to which extent the new brood of $P$. canaliculata can tolerate the extreme high temperature during Summer period at Shatt Al-Arab habitat?, the results of the present study indicates that the snail population can't be longer tolerate to the high extreme temperatures faced during the Summer season when the temperature exceed $45^{\circ} \mathrm{C}$ during the exposure period at the day low tide. According to our observations, the eggs of the snail laid down on the emergent parts of the Typha plants, just above the water level, and when they hatch they drop into a shallow water places ( a few centimeters height) before they find their way to the upper intertidal zone. Under this condition, the new broods of the snails are subjected to extreme warm substrate due to the direct exposure to sun for a period of several hours during the day-low tide cycle, and therefore the snails become incapable to balance their thermal budget.

The main goal of heart rate measurements is to predict the metabolic rates in a simple technique (22), which is, representing the main component of the energy budget of an organism (23), however, studies concerning the relationships between the heart rate and the metabolic rate in invertebrates, although indicating a significant correlation at the individual level, they stressed that the relation showed differences according to the geographic location and between isolated groups across populations (30). Therefore, further explorations are needed to confirm this relationship.

In conclusion, the present results expected that $P$. canaliculata as an exotic species, will have only limited dispersal in the intertidal zone of the Shatt Al-Arab and may no longer tolerate living in this habitat.

\section{Acknowledgements}

We thank Prof. Nadia Al-Mudaffar Fawzi (University of Basrah, Marine Science Center) for reading the manuscript.

\section{Authors' declaration:}

- Conflicts of Interest: None.

- We hereby confirm that all the Figures and Tables in the manuscript are mine ours. Besides, the Figures and images, which are not mine ours, have been given the permission for republication attached with the manuscript.

- The author has signed an animal welfare statement.

- Ethical Clearance: The project was approved by the local ethical committee in University of Basrah.

\section{References:}

1. Yoshida K, Yusa Y, Yamanishi Y, Matsukura K, Wada T. Survival, growth and reproduction of the invasive apple snail Pomacea canaliculata in an irrigation canal in southern Japan., 2016; J. Molluca Stud. 82(4): 202-600.

2. Yang Q, Liu S, He C, Ya X. Distribution and the origin of invasive apple snail, Pomacea canaliculata and $P$. maculata (Gastropoda: Ampullariidae) in China. Sci. Rep. 2018; number: 8, Article 1185.

3. López MA, Altaba CR, Andree KB, López V. First invasion of the apple snail Pomacea insularum in Europe. Tentacle, 2010; 18:26-28.

4. Guo J, Zhang C, Xiang Y, Zhang J, Liang $\mathrm{K}$. Biological control of the exotic invasive snail Pomacea canaliculata with the indigenous medicinal leech Whitmania pigra. J. Biocontrol Sci. Technol. 2017; 27(9):1071-1081.

5. Al-Jassany RF, Al-Hassnawi MN. New record of the golden apple snail Pomacea canaliculata in Iraq. Arab J. Plant Prot. 2017; 35(1): 43-47.

6. Al-Khafaji KK, Al-Esaa S AK, Hashim AA. The density, abundance and distribution of the Macroinvertebrates community in the intertidal zone of the Shatt Al-Arab, South-Iraq. Thi Qar J. Sci. 2015; 5(2): 54-64.

7. Liu C, Zhang Y, Ren Y, Wangtt H, Li S, Jiang F, et al. The genome of the golden apple snail Pomacea canaliculata provides insight into stress tolerance and invasive adaptation, Giga Sci. 2018; 7(9): 1-13.

8. Maldonado MA, Martin PR. Dealing with hypersuccessful neighbor: effect of invasive apple snail Pomacea canaliculata on exotic and native snail in South America. In press in Curr. Zool. 2018; https://doi.org/10.1093/cz/zoy060.

9. Ahmed MM. Systematic study on Mollusca from Arabian Gulf and Shatt Al-Arab. Center for Arab Gulf Stu., Basrah Univ. Iraq, 1975; 75 pp.

10. Lathlean JA, Ayre DJ, Minchinton E. Estimating latitudinal variability extreme heat stress on rock intertidal shores. J. Biogeogr. 2014; 41(8), http://doi.org/10.1111/jbi.12311.

11. Bellared C, Jeschke JM, Leory B, Mace GM. Insights from modeling studies on how climate change affects invasive alien species geography. Ecol. Evol. 2018; 8(11): 5688-5700.

12. Birchenough SN, Reiss H, Degraer S, Mieszkowska $\mathrm{N}$, Borja A, Buhl U, et al. Climate change and marine benthos: a review of existing research and future directions in the North Atlantic. WIREs Clim. Change 2015. Doi: 1002/ecc.330. 
13. Doney SC, Ruckelshaus M, Duffy JE, Barry JP, Chan F, English CA, et al. Climate change impact on marine ecosystems. Ann. Rev. Mar. Sci. 2012; 4: 1157

14. UNIP. The Mesopotamian marshlands: Demis of an Ecosystem, 2001(UNIP/DEWA/ TR. 01-3), 115 pp.

15. Salman SD, Ali MH, Al-Adhub AH Y. Abundance and seasonal migration of the Penaeid shrimp Metapenaeus affinis (H.Milne-Edward) within Iraqi waters. Hydrobiologia 1990; 196: 79-90.

16. Ali MH, Salman SD. The reproductive biology of Parhyale basrensis (Crustacea: Amphipoda) in the Shatt Al-Arab River. Estuar. Coast. Shelf Sci. 1986; 23(3): 339-351.

17. Ali MH, Salman SD. Growth and production of the Amphipod Parhyale basrensis (Talitridae) in the Shatt Al-Arab region. Mar. Ecol. Prog. Ser. 1987. 23; 40: 231-238.

18. Tagliarolo M, McQuaid CD. Field measurements indicate unexpected, serious underestimation of mussel heart rates and thermal tolerance by laboratory studies. 2016 PLOS ONE 11(2): e0146341.

19. Pautsina A, Kuklina I, Stys D, Cisar R, Kozak P. Noninvasive crayfish cardiac activity monitoring system. Limnol. Oceanogr. Methods. 2014; 12:670679.

20. Feket-Kertesz I, Styrling T, Ullmann O, Farkas E, Kirchkeszner C, Fiegl V, et al. How dose experimental design modify the result of Daphnia magna heartbeat rate test?- analyses of factors affecting the sensitivity of the test system. Period. Polytech. Chem. Eng. 2018; 62(3): 257-264.

21. Helliear AD, Rahman A, Smith D, McCulloh JA. Neural network and some based approach to analyses periodic signals: application to oyster heart-rate data in IEEE international joint conference on neural network (IJCNN) (Bijing), 2018; 2211-2217.

22. Armstrong JD. Heart rate as an indicator of activity, metabolic rate, food intake and digestion in pike, Esox lucius. J. Fish Biol. 1986; (29): 207-221.

23. Bruning A, Gonzalé A, Gaitán-Espitia JD, Bartheld JL, Toader-Williams A, Mondaca F, Nespolo RF, et al. Energy, metabolism, heart rate and physiological differentiation in the Pulmonate gastropod Cornu aspersum. J. Mollusca Stud. 2013; 79(3,1): 257-262.

24. Everatt MJ, Bale JS, Convey P, Worland MR, Hayward SAL. The effect of acclimation temperature on thermal activity thresholds in polar terrestrial invertebrates. J. Insect Physiol. 2013; 59(10): 10571064.

25. Shah AA, Funk WC, Ghalambor CK. Thermal acclimation ability varies in temperate and tropical aquatic insect from different elevations. Integration Corpotation Biol. 2017; 57(5): 977-987.

26. Domnik NJ, Polymeropoulose ET, Elliott NG, Frappel PB, Fisher J.T. Automated non-invasive video-microscopy of Oyster spat heart rate during acute temperature change: impact of acclimation temperature. Front Physiol. 2016; 22 http://doi.Org/10.3389/fph.2016.00236.

27. Iontanini A, Steckbauer A, Dupont S, Duarte CM. Variable metabolic responses of Skagerrak invertebrates to low $\mathrm{O}_{2}$ scenarios. Biogeosci. 2018; 15: 3717-3729.

28. Drost HE, Fisher J, Randall F, Kent D, Carmack EC, Farrell AJ. Upper thermal limits of the hearts of aratic cod Boreoqadus saida: adult compared with larvae. J. Fish Biol. 2015; 88: 718-726. Pmid: 26608719.

29. Moyano M, Candebat C, Ruhbaum Y, AlvarezFernandez S, Claireoux G, Zambonino-Infant JL, et al. Effect of warming rate, acclimation temperature and ontogeny on the critical thermal maximum of temperature marine fish larvae. PLOS ONE, 2017; http://doi.org/10.1371/journal-pone-0179928.

30. Halsey L, Green JA, Twiss SD, Careau V. Flexibility variability and constraint in energy management patterns across taxa revealed by long-term heart rate measurement. Funct. Ecol. 2018; 33(1): 260-272.

31. Sara G, Milanese M, Prusina I, Sara A, Angel DL, Glamuzina B, et al. The impact of climate change on Mediterranean intertidal communities: losses in coastal ecosystem integrity and services. Reg. Environ. Change 2014; 14(1): 5-17.

32. Kearney M, Simpson SJ, Raubenheimer DR, Helmuth B. Modeling the ecological niche from functional traits. Phil. Trans. R. Soc. B., 2010; 365: 3469-3483. 
تأثير درجة الحرارة على نثاط قلب الحلزون Pomacea canaliculata (Lamarck, 1819 من منطقة

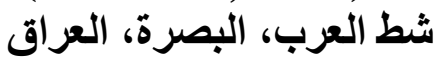

هدى كاظم أحمد
هناء حسين محمد

$$
\text { ماللك حسن علي }
$$

مركز علوم البحار، جامعة البصرة، البصرة، العراق.

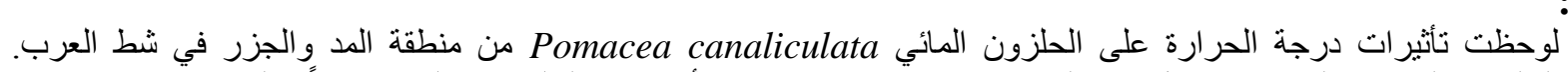

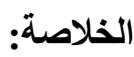

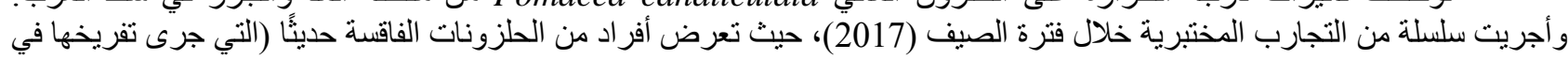

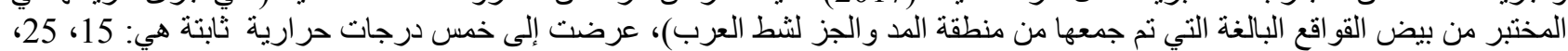

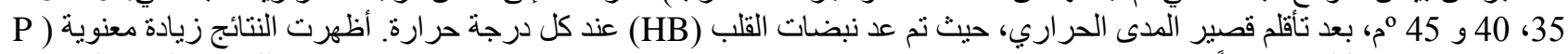

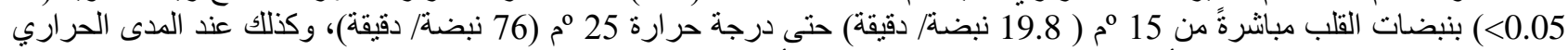

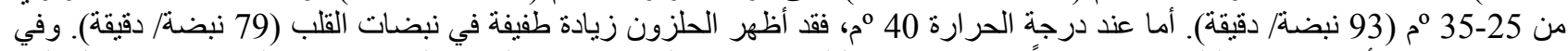

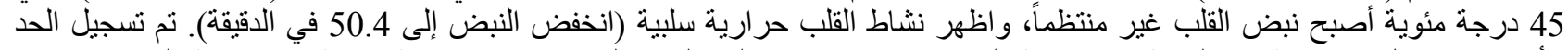

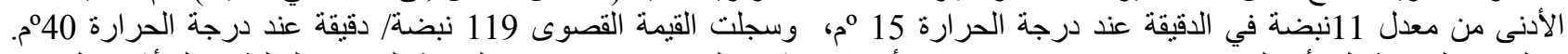

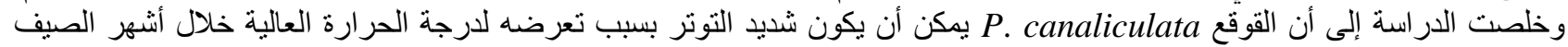
الطويلة وسوف لن يعد لديه التحمل للعيش في منطقة المد و الجزر لثط العرب العرب.

الكلمات المفتاحية: نبضات القلب، درجات الحر ارة، منطقة الدد والجزر، شط العرب، P. canaliculata. 